\title{
Evaluation of Iranian Second-Grade High School English Textbook from Teachers' Perspectives
}

\author{
Karim SHABANI ${ }^{1}$, Fatemeh SAFARI ${ }^{2, *}$ \\ ${ }^{1}$ Allameh Mohaddes Nouri University, Nour, Iran \\ E-mail: shabanikarim@gmail.com \\ ${ }^{2}$ Allameh Mohaddes Nouri University, Nour, Iran \\ E-mail: f.hsafari2010@gmail.com
}

\begin{abstract}
Among the various tools in educational contexts to affect L2 learners' language proficiency, textbooks play a crucial role (Garinger, 2001) not least because of their inherent property to cater to the learners' specific needs. The aim of this study was to investigate the appropriateness of Iranian High schools "English Textbook 2" from teachers' perspectives. For this purpose, 80 male and female experienced English language teachers were randomly selected from different high schools in Dezful, Iran. They were chosen based on the availability sampling method. The evaluation of the textbook was conducted quantitatively through a 5-point Likert scale checklist which was proposed by Litz (2005). The textbook evaluation scheme contained 19 items which relied upon four main criteria namely a) layout and design, b) subject and content, c) activities, and d) skills (see Appendix). The results indicated that from the teachers' perspective there was an incongruity between the presumed educational purposes and the teachers and learners' needs. It is believed that the results of the study could provide intriguing hints for the curriculum designers and materials developers to think of adapting the available materials or adopting an alternative textbook which contains an organized layout, useful and real-life subjects and contents, covers relevant skills and activities, and corresponds to teachers' and learners' emerging needs.
\end{abstract}

Keywords: Textbook evaluation, Curriculum designers, Material developers.

\section{Introduction}

Textbooks are one of the inherent factors that should be considered in the realm of language teaching and learning (Riazi, 2003). Riazi argued that in the context of second/foreign language classroom, textbook is the second important factor after the role of teacher. Moreover, Garinger (2001) claimed that textbooks have significant effects on language learning processes in classrooms. According to Tomlinson (2011), a textbook is defined as a book which establishes the basic resources for a language-learning course. Nunan (1999, p. 98) claimed that "a textbook is the main component of any instructional program and it is difficult to imagine a class without 
it". According to Litz (2001), in the case of teaching (ELT) programs, textbooks have been perceived as the preliminary requirements in accomplishing the students' purposes and needs. In order to achieve the principal objectives of learning a second/foreign language, teachers should select the most appropriate textbooks that adjust the criteria, teachers' and learners' specific situations, and also their purposes and needs. However, Ramzjoo (2010) argued that in some settings, the majority of teachers are not free to choose their own textbooks. They should choose the textbooks which have been suggested to them.

In addition, Abdelwahab (2013) claimed that using a textbook in a program "can guarantee that students in different classes will receive a similar content and therefore, can be evaluated in the same way" (p. 55). Richards (2001) also highlighted the critical role of textbooks claiming that since textbooks provide structure and a syllabus, learning might not have any impact if the teaching course doesn't contain textbooks.

With regard to the benefits and harms of using textbook in the classrooms, there have been controversial claims. In this line, Garinger (2002) argues that instructors should consider the appropriate use of textbooks as well as learners' specific needs and purposes.

Nunan (1999) mentioned the significant role of textbooks as the main aspect of any instructional syllabus. He contended that language learning processes in a classroom might not prosper without providing textbooks. Therefore, in order to choose the most appropriate textbook, we need to evaluate the suitability of using them in the context of language learning classrooms. Sheldon (1988) argued that for evaluating textbooks, there are two primary reasons: 1) teachers can select the most appropriate textbooks more easily 2) teachers can be familiarized with merits and demerits of a textbook. There have been various definitions of the term "evaluation". For instance, Hutchinson and Waters (1993) defined it as a "matter of judging the fitness of something for a particular purpose" (p. 96). According to Dudley-Evans and John (2005), "evaluation is a whole process which begins with determining what information to gather and ends with bringing about change in current activities or influencing future ones" (p. 128).

Considering the fact that learning English (especially through using suitable textbooks) has gained more importance in the context of Iran during recent decades, examining the efficacy of textbooks is of crucial concern. Therefore, the aim of this study was to evaluate the "English textbook 2" of Iranian high school students from teachers' perspectives.

\subsection{Research questions}

The study therefore addresses the following research questions:

1) To what extent is the "English textbook 2" appropriate for Iranian high school students in terms of layout and design?

2) To what extent is the "English textbook 2" appropriate for Iranian high school students in terms of subject and content?

3) To what extent is the "English textbook 2" appropriate for Iranian high school students in terms of activities? 
4) To what extent is the "English textbook 2" appropriate for Iranian high school students in terms of language skills?

\section{Literature Review}

As textbooks establish a beneficial source for both teachers and learners, considering their role in language teaching and learning contexts is of crucial concern (Ahour, Towhidiyan, \& Saeidi, 2014). Many scholars and teachers believe that after the role of teacher, coursebook is the second important factor in language learning classrooms (Davison, 1975; Riazi, 2003).

Ahour, Towhidiyan, and Saeidi (2014) claimed that textbooks are considered as the main sources of learning which help students to accomplish their needs and objectives. Ahour and Ahmadi (2012) mentioned the role of textbook as a means of gaining knowledge and information and argued that "textbooks are the main sources that convey the knowledge and information to the learners in an easy and organized way" (p. 176).

According to Prabhu (1987), textbooks are fully determined and pre-prepared materials that establish a certain amount of equality in what happens in many various language learning classes with various instructors and students, which serve the benefits of accountability.

Based on the works of many researchers there are many various reasons for evaluating textbooks. For instance, Hutchinson and Waters (1993, p. 96) claimed that materials evaluation should be carried out to ascertain the suitability of those materials to our specific needs. In addition, Hutchinson (1987) stated that materials evaluation provides a clear path for teachers to increase their awareness toward the nature of language teaching and learning and also to select their teaching materials wisely. Furthermore, Sheldon (1988) argued that all the textbooks in the field of English language teaching should have some criteria such as effectiveness, considerable features, and fitness. Moreover, according to Cunningsworth (1995) there are two main reasons for textbook evaluation. Firstly, material evaluation helps teachers to adopt new coursebooks. Secondly, it helps teachers to discover the peculiar strengths and weaknesses in coursebooks that have been used in classes. Regarding the advantages of materials evaluation, Littlejohn (2011) claimed that "materials analysis and evaluation enable us to look inside the materials and to take more control over their design and use" (p. 183). Evaluation helps teacher to be knowledgeable of the organizational origins of the materials and also to keep up with progresses in the field of language learning and teaching and consequently to adjust materials realistically (Ahour, Towhidiyan, \& Saeidi, 2014). In this regard, McDonough and Shaw (2003,) mentioned the role of evaluation as "a useful process in its own right" (p. 60).

According to Cunningsworth (1995) and Ellis (1997) there are three different kinds of material evaluation: 1) pre-use, 2) in-use, and 3) post-use. The 'pre-use' or 'predictive' evaluation was considered as the most common type that was developed to investigate the potential efficiency of a textbook. The 'in-use' evaluation was designed to investigate material that was currently being used. Finally, the 'post-use' or 'retrospective' evaluation of a coursebook that has been applied in any respective language institution. 
Therefore, since textbook has a great impact on the effectiveness of teaching and learning a foreign/second language, selecting the most appropriate one is worth considering and examining for both teachers and learners. Thus, in order to develop the process of language teaching and learning, an evaluation of textbook is needed. In this regard, the aim of this study was to evaluate the appropriateness of Iranian High schools "English Textbook 2" from the teachers' perspectives.

\subsection{Empirical Studies on Textbook Evaluation}

Due to the crucial role of textbook evaluation, many researchers have worked on examining the suitability of this issue. In order to evaluate different textbooks in different contexts, they tried to use various textbook evaluation schemes. For instance, in South Korea, Litz (2005) examined the appropriateness of "English Firsthand 2" textbook, which was taught at Sung Kyun Kwan University in Suwon, South Korea. In conclusion, he mentioned some advantages of this textbook, though, it is not a well-known textbook. For example, the entire textbook package has a variety of beneficial supplementary materials. It has a logical and coherent organization. It also contains the integration of the four language skills (reading, listening, speaking, and writing). In addition, it had the other important ELT elements such as vocabulary development. However, it failed to encourage meaningful and realistic practices. Generally, it failed to internalize the language.

In another study, Tok (2010) investigated appropriateness of "Spot on" textbook which was used in state primary schools in Turkey. In this study, results have revealed some advantages and disadvantages. For advantages, he concluded that the teacher's guide books are highly useful. The content of the textbook has realistic, interesting, and motivating features, and also contains incorporating pair and group work. However, for disadvantages, he mentioned the low quality of design and layout of the textbook. He also claimed that the textbook activities do not reflect communicative purposes and meaningful practices.

Ansary (2004) evaluated the strengths and weaknesses of Iranian High school English textbooks. According to him, the designs of these textbooks are not attractive, usable, and durable. The other demerit is the little use of pictures and illustrations and thus they were not attractive for the students. In addition, the instructions of illustrations were not understandable. Moreover, in the reading parts, the background knowledge of the students was neglected and they were not organized according to their difficulty level.

Furthermore, Ghorbani (2011) investigated appropriateness of "English Book 1" which was used in Iranian senior high schools. For this purpose, he created a new checklist. Results have revealed that the book was found to have high physical qualities (such as paper quality, binding, printing, etc.). However, it lacks the integration of four language skills. There was not much attention to communicative tasks and activities. In addition, it failed to have reference materials such as audio CDs or student's and teacher's guides. The other weakness is that, there was not any glossary at the end of the book.

Ahour1, Towhidiyan1 and Saeidi (2014) in a quantitative study evaluated the merits and demerits of Iranian High schools "English Textbook 2" from the teachers' perspectives. In order to accomplish the purpose of this study, an adapted checklist (developed by Litz, 2005) was 
used. Generally, results have revealed that the overall teachers' perspectives toward this textbook were not favorable. The results of this study could be beneficial for syllabus and designers and materials developers in Ministry of Education. They suggested that it is better to revise it or adopt a new textbook.

Finally, in a more recent study, Rashidi and Kehtarfard (2014) investigated appropriateness of "English Book 3" which was used in Iranian high schools, by using the needs analysis questionnaires. Generally, they concluded that this textbook failed to integrate the four language skills (reading, listening, speaking, and writing). They suggested that materials developers and syllabus and curriculum designers should revise the current textbook.

Thus, taking these points into consideration, the main objective of the present research study was to examine the appropriateness of Iranian High schools "English Textbook 2" from the teachers' perspectives.

\subsection{Methodology}

In this section, some details related to the participants, instruments, procedures, data collection and analysis are explained.

\subsection{Participants}

In this study, 80 male and female experienced English language teachers were selected from different high schools in Dezful, Iran. As the researcher believed that availability sampling could be a representative of the accessible and the target population; in the present research study, this type of sampling was used and thus participants were selected through availability sampling.

\subsection{Design}

This study relied upon a survey-based quantitative design to meet its purposes. Hence, a Likert scale questionnaire proposed by Litz (2005) was chosen to be distributed among the participants. Results of responses to the questionnaire were measured quantitatively.

\subsection{Instruments}

The study used textbook, and textbook evaluation checklist as instruments.

\subsection{Textbook}

Since according to some teachers and students' attitudes, English textbook 2 (among English textbooks of the high school) was considered as the one which had more weaknesses; "English Textbook 2" (written by Birjandi, Noroozi, \& Mahmoodi, 2012) was chosen as the textbook for the purpose of evaluation. This textbook which was approved by Ministry of Education in Iran was used to teach English to second grade students in high schools. Students in high schools attended classes for learning this textbook twice a week (containing 2 hours).

\subsection{Textbook evaluation checklist}


The other instrument used in this study was a 5-point Likert scale checklist which was proposed by Litz (2005) which contain four main criteria (subject and content, activities, and skills). Considering 20 experienced teachers' views, English textbook 2 mostly lacks the high quality of four important criteria containing layout and design, subject and content, activities and skills as compared with other criteria in Litz' (2005) checklist. For the purpose of the current study, these parts containing 19 specific items were taken from this questionnaire. In addition, for the convenience of statistically coding, the questionnaire was simplified to Completely Disagree $=1$, Disagree $=2$, Moderately Agree $=3$, Agree $=4$, Completely Agree $=5$ (5-point Likert scale) . Then, the content validity of the checklist was confirmed by three educational experts and four experienced teachers. In addition, the pilot study indicated the validity of the questionnaire for the context of Iran. Likewise, for measuring internal reliability (consistency) of the items in the questionnaire, Cronbach Alpha coefficient was used and based on results value ( $\alpha: .98)$, a very high internal consistency reliability obtained.

\subsection{Procedures}

For this study, the quantitative results were collected through the teacher textbook evaluation checklist. To this end, firstly the researcher has asked the permission from the officials in the Education Administration. Then, data were generated through responses by 80 experienced English teachers to the textbook evaluation (proposed by Litz, 2005). These teachers were selected randomly from various high schools in Dezful, Iran. Textbook evaluation questionnaires were administered at the end of the second semester in the academic year 2015-2016. In order to collect the results of the current study, the researcher qualified its primary objectives before distributing the checklists. The findings were entered into the SPSS 22.0 for later analysis. The descriptive statistics including mean, standard deviation, frequency, percentage were applied in the data analysis.

\subsection{Data collection}

In order to evaluate the textbook from teachers' viewpoints, data were collected at the end of the educational year. Before administering the questionnaires, the researcher explained the principal objectives of the study and also the aims of each part and item of the checklist because she assumed it would help elicit real responses from the participants. In the next phase, for data collection a closed-ended questionnaire proposed by Litz (2005) was distributed to the participants. For the purpose of the current study, 17 particular questions were selected from this checklist. Finally, to investigate the results, descriptive statistics were used.

\subsection{Analysis}

To analyze the results obtained from the administered close-ended questionnaire, data were transformed to numeric results and descriptive statistics were applied through using the SPSS software (version 22.0). 


\section{Results}

The aim of this study was to evaluate the appropriateness of "English textbook 2" of Iranian high school students from teachers' perspectives. Therefore, this section presents the results of the current study. The evaluation focuses on four main criteria namely, 'layout and design, subject and content, activities, and skills'.

The results of the study including means, standard deviations, frequencies, and percentages of items were estimated to summarize and describe the responses of teachers. The findings of each item that relate to a particular criterion are presented in tables and explanations are described accordingly.

\subsection{Results of Data Analysis for Research Question 1}

Regarding the first research question: 'To what extent is the "English textbook 2" appropriate for Iranian high school students in terms of layout and design?', teachers' responses to the first section (layout and design) of the Litz's (2005) checklist which contained two items were considered and results were estimated (see Table 1).

Table 1: Means, standard deviations, frequencies, and percentages of the items on subject and content

\begin{tabular}{ccccccccccccc}
\hline Textbook evaluation scales & 1 & & 2 & 3 & & 4 & & & & \\
\hline Layout and Design & $n \%$ & $n$ & $\%$ & $n$ & $\%$ & $n$ & $\%$ & $n$ & $\%$ & $M$ & $S D$ \\
\hline Item 1 & 5973.8 & 13 & 16.3 & 4 & 5.0 & 2 & 2.5 & 2 & 2.5 & 1.43 & .89 \\
Item 2 & 1721.3 & 18 & 22.5 & 12 & 15.0 & 15 & 18.8 & 18 & 22.5 & 1.25 & .64 \\
\hline
\end{tabular}

Note: Completely Disagree $=1$, Disagree $=2$, Moderately Agree $=3$, Agree $=4$, Completely Agree $=5$

As Table 1 indicates, majority of the teachers $(90 \%)$ responded unfavorably to item $1(\mathrm{M}=1.43$, $\mathrm{SD}=.89$ ). They stated that the layout and design of the textbook were not appropriate for language learning processes.

For item 2, a large number of the teachers $(93.8 \%)$ responded unfavorably to this item $(\mathrm{M}=1.25$, $\mathrm{SD}=.64)$. They mentioned that the layout and design of the book were not prepared appropriately and effectively.

\subsection{Results of the Data Analysis for Research Question 2}

Regarding the second research question: "To what extent is the "English textbook 2" appropriate for Iranian high school students in terms of subject and content?', teachers' responses to the first 
section (subject and content) of the Litz's (2005) checklist which contained five items were considered and results were estimated (see Table 2).

Table 2: Means, standard deviations, frequencies, and percentages of the items on subject and content

\begin{tabular}{ccccccccccccc}
\hline Textbook evaluation scales & 1 & & 2 & & 3 & & 4 & & 5 \\
& Subject and Content & $n \%$ & $n$ & $\%$ & $n$ & $\%$ & $n$ & $\%$ & $n$ & $\%$ & $M$ & $S D$ \\
\hline Item 3 & 4860 & 13 & 16.3 & 3 & 3.8 & 10 & 12.5 & 6 & 7.5 & 1.91 & 1.35 \\
Item 4 & 5670 & 11 & 13.8 & 3 & 3.8 & 7 & 8.8 & 3 & 3.8 & 1.62 & 1.14 \\
Item 5 & 6581.3 & 9 & 11.3 & 2 & 2.5 & 4 & 5.0 & - & - & 1.32 & .77 \\
Item 6 & 6176.3 & 10 & 12.5 & 1 & 1.3 & 6 & 7.5 & 2 & 2.5 & 1.47 & 1.00 \\
Item 7 & 1721.3 & 18 & 22.5 & 12 & 15.0 & 15 & 18.8 & 18 & 22.5 & 2.98 & 1.47 \\
\hline
\end{tabular}

Note: Completely Disagree $=1$, Disagree $=2$, Moderately Agree $=3$, Agree $=4$, Completely Agree $=5$

As Table 2 indicates, almost two third of the teachers (76.3\%) responded unfavorably to item 3 $(\mathrm{M}=1.91, \mathrm{SD}=1.35)$. They stated that the subject and content of the textbook did not correspond to students' needs and educational purposes.

For item 4, a large number of the teachers $(83.8 \%)$ responded unfavorably to this item $(\mathrm{M}=1.62$, $\mathrm{SD}=1.14)$. They stated that the textbook subject and content was not generally realistic.

Item 5 shows that, a vast majority of the teachers (92.6\%) believed that the textbook subject and content was not interesting, challenging, and motivating $(\mathrm{M}=1.32, \mathrm{SD}=.77)$.

According to item 6 , most of the teachers $(88.8 \%)$ responded unfavorably to this item $(M=1.47$, $\mathrm{SD}=1.00$ ). They stated that there is not sufficient variety in the subject and content of the textbook.

As Table 2 indicates, while almost half of the teachers (43.8\%) responded unfavorably to item 7 $(\mathrm{M}=2.98, \mathrm{SD}=1.47), 56.3 \%$ stated that materials are not culturally biased and do not portray any negative stereotypes.

\subsection{Results of the Data Analysis for Research Question 3}

Regarding the third research question: 'To what extent is the "English textbook 2" appropriate for Iranian high school students in terms of activities?', teachers' responses to the second part (activities) of the Litz's (2005) checklist which contained seven items were measured and results were estimated (see Table 3). 
Table 3: Means, standard deviations, frequencies, and percentages of the items on activities

\begin{tabular}{|c|c|c|c|c|c|c|c|c|c|c|c|c|}
\hline Textbook evaluation scales & & 1 & & 2 & & 3 & 4 & & & 5 & & \\
\hline Activities & $\mathrm{n}$ & $\%$ & $\mathrm{n}$ & $\%$ & $\mathrm{n}$ & $\%$ & $\mathrm{n}$ & $\%$ & $\mathrm{n}$ & $\%$ & M & SD \\
\hline Item 8 & 53 & 66.3 & 16 & 20.0 & 5 & 6.3 & 6 & 7.5 & - & - & 1.55 & .91 \\
\hline Item 9 & 56 & 70.0 & 13 & 16.3 & 5 & 6.3 & 4 & 5.0 & 2 & 2.5 & 1.53 & .99 \\
\hline Item 10 & 36 & 45.0 & 17 & 21.3 & 8 & 10.0 & 11 & 13.8 & 8 & 10.0 & 2.22 & 1.40 \\
\hline Item 11 & 49 & 61.3 & 17 & 21.3 & 3 & 3.8 & 6 & 7.5 & 5 & 6.3 & 1.76 & 1.21 \\
\hline Item 12 & 52 & 65.0 & 18 & 22.5 & 6 & 7.5 & 4 & 5.0 & - & - & 1.52 & .84 \\
\hline Item 13 & 57 & 71.3 & 7 & 8.8 & 4 & 5.0 & 8 & 10.0 & 4 & 5.0 & 1.68 & 1.23 \\
\hline Item 14 & 23 & 28.7 & 19 & 23.8 & 6 & 7.5 & 15 & 18.8 & 17 & 21.3 & 2.80 & 1.55 \\
\hline
\end{tabular}

Note: Completely Disagree $=1$, Disagree $=2$, Moderately Agree $=3$, Agree $=4$, Completely Agree $=5$

Item 8 shows that, a huge number of the teachers $(86.3 \%)$ believed that the textbook did not provide a balance of activities and the exercises could not provide opportunities for learners to improve their language proficiency including their accuracy and fluency $(\mathrm{M}=1.55, \mathrm{SD}=.91)$.

For item 9, most of the teachers (86.3\%) responded unfavorably to this item $(\mathrm{M}=1.53, \mathrm{SD}=.99)$. They stated that the textbook activities did not correspond to the students' communicative purposes.

According to item 10, whereas most of the teachers completely disagreed and disagreed $(66.3 \%)$ with the appropriateness of the textbook activities in terms of individual, pair, and group work; $33.8 \%$ of them agreed with this item $(\mathrm{M}=2.22, \mathrm{SD}=1.40)$.

For item 11, majority of the teachers (82.6\%) responded unfavorably to this item $(\mathrm{M}=1.76, \mathrm{SD}$ $=1.21$ ). They claimed that since the textbook activities were not motivating and did not contain realistic contents, they could not correspond to the students' educational needs in terms of learning through grammar points and vocabularies of the textbook.

As item 12 indicates, most of the teachers $(87.5 \%)$ responded unfavorably to this item $(\mathrm{M}=1.52$, $\mathrm{SD}=.84)$. They stated that the textbook activities did not promote creative, original, and independent responses.

Item 13 indicates that, a large number of the teachers $(80.1 \%)$ responded unfavorably to this item $(\mathrm{M}=1.68, \mathrm{SD}=1.23)$. They stated that the tasks of the textbook were not conducive to the introduction of newly introduced language and argued that the tasks were not introduced in meaningful situations to facilitate understanding. 
As Table 1 indicated, while more than half of the teachers $(52.5 \%)$ responded unfavorably to item 14, 47.6\% of the teachers stated that activities of this textbook can be modified or supplemented easily $(\mathrm{M}=2.80, \mathrm{SD}=1.55)$.

\subsection{Results of the Data Analysis for Research Question 4}

Regarding the last research question: 'To what extent is the "English textbook 2" appropriate for Iranian high school students in terms of language skills?', teachers' responses to the fourth section (language skills) of the Litz's (2005) checklist which contained five items were considered and results of them were estimated (see Table 4).

Table 4: Means, standard deviations, frequencies, and percentages of the items on skills

\begin{tabular}{|c|c|c|c|c|c|c|c|c|c|c|c|}
\hline Textbook evaluation scales & 1 & & 2 & & 3 & & 4 & & 5 & & \\
\hline Skills & $n \%$ & $n$ & $\%$ & $n$ & $\%$ & $n$ & $\%$ & $n$ & $\%$ & $M$ & $S D$ \\
\hline Item 15 & 4556.3 & 17 & 21.3 & 3 & 3.8 & 7 & 8.8 & 8 & 10.0 & 1.95 & 1.36 \\
\hline Item 16 & 6378.8 & 9 & 11.3 & 2 & 2.5 & 2 & 2.5 & 4 & 5.0 & 1.46 & 1.04 \\
\hline Item 17 & 7188.8 & 5 & 6.3 & 2 & 2.5 & 2 & 2.5 & - & - & 1.18 & .59 \\
\hline Item 18 & 6581.3 & 6 & 7.5 & 4 & 5.0 & 2 & 2.5 & 3 & 3.8 & 1.37 & .95 \\
\hline Item 19 & 5973.8 & 10 & 12.5 & 3 & 3.8 & 2 & 2.5 & 6 & 7.5 & 1.57 & 1.17 \\
\hline
\end{tabular}

Note: Completely Disagree $=1$, Disagree $=2$, Moderately Agree $=3$, Agree $=4$, Completely Agree $=5$

For item 15 most of the teachers $(77.6 \%)$ responded unfavorably to this item $(\mathrm{M}=1.95, \mathrm{SD}=$ 1.36). They declared that materials did not include the skills which could improve students' language proficiencies.

Item 16 shows that, majority of the teachers $(90.1 \%)$ believed that the textbook did not provide an appropriate balance of the four language skills $(\mathrm{M}=1.46, \mathrm{SD}=1.04)$.

According to item 17, a huge number of the teachers (95.1\%) responded unfavorably to this item $(\mathrm{M}=1.18, \mathrm{SD}=.59)$. They stated that the materials did not include sufficient and suitable subskills.

As Table 2 indicates, most of the teachers $(88.8 \%)$ responded unfavorably to item $18(\mathrm{M}=1.37$, $\mathrm{SD}=.95)$. They claimed that the textbook did not contain natural pronunciation tasks and practices.

Item 19 shows that, majority of the teachers $(86.3 \%)$ believed that the practice of the individual skills was not integrated into the practice of other skills. Therefore, meaningful communication was not promoted by referring to realistic skills and activities $(\mathrm{M}=1.57, \mathrm{SD}=1.17)$. 


\section{Discussion}

Materials evaluation helps researchers, teachers, and learners to look inside the materials and therefore be able to control their design and usage (Littlejohn, 2011). For the purpose of this study, the appropriateness of "English textbook 2" was investigated according to 80 teachers' attitudes in terms of four main criteria (layout and design, subject and content, activities, and skills) of a textbook evaluation checklist proposed by Litz (2005).

According to the teachers' beliefs, the layout and design of the textbook was not established effectually. For instance, teachers stated that the textbook did not contain suitable warm-up activities, listening and speaking tasks failed to persuade students for communicating successfully. Another shortcoming was that the vocabulary and grammar points were not designed effectively. The results generated through responses to this section contradicted with the findings of Litz (2001) who investigated the appropriateness of "English Firsthand 2".

Regarding evaluating the subject and content of the textbook, the findings including means and standard deviations indicated that most of the teachers were not satisfied with the textbook subject and content. Based on a vast majority of the teachers, the subject and content of the textbook were not relevant to the students' needs, were not motivating and interesting, and did not contain realistic features and sufficient varieties. However, the highest mean (2.98) in the 'Subject and Content' part was related to the item 7. In responding to this item, almost half of the teachers believed that materials were culturally biased. In this regard, the findings of this study were in agreement with the work of Ahour, Towhidiyan, and Saeidi (2014).

According to the results obtained from the "activities" part, most of the teachers responded unfavorably to the items of this section. The findings indicated that the textbook did not provide a balance of activities which could help language learners to be more fluent and accurate. They claimed that the activities could not encourage sufficient communicative meaningful tasks and could not incorporate individual, pair, and group work. However, according to many scholars such as Widdowson (1983) and Grant (1987), in order to help students to be able to communicate and speak in the target language, any language activity and program should contain useful and meaningful communicative tasks and activities. Moreover, teachers mentioned that grammar points and vocabulary items were not introduced in motivating and realistic contexts. They also stated that the textbook activities could not promote creative, original, and independent responses. In addition, they believed that the tasks were conductive to the internalization of newly introduced language. On the other side, according to more than half of the teachers' viewpoints, textbook activities could be modified or supplemented easily. Regarding section "activities", while findings of the items 8, 9, 10, 11, 12 and 13 contradicted with the work of Riasati and Zare (2010), results of the last item (14) of this section were in line with the work of theses researchers (Riasati \& Zare, 2010). Moreover, the findings of this section were in line with the works' of Ansary (2004) and Ahour, Towhidiyan, and Saeidi (2014).

With respect to the last part "skills", means and standard deviations of the outcomes showed that majority of the teachers disagreed on the appropriateness of English textbook 2. According to 
teachers' perspectives, results revealed that the textbook did not include and focus on the skills that the students need to improve their language proficiency. In addition, they claimed that the textbook did not establish an appropriate balance of the four basic language skills and there was not much attention to sub-skills. Furthermore, teachers stated that the textbook did not highlighted natural pronunciation. Finally, according to most of the instructors, the practice of individual skills was not integrated into the practice of other skills. The results of this study regarding the "skills" section were in agreement with the findings of many researchers such as Ansary (2004), Ghorbani (2011), and Ahour, Towhidiyan, and Saeidi (2014). On the other hand, the results of the "skills" section of the current study contradicted with the findings of Riasati and Zare (2010) who evaluated the appropriateness of New Interchange Series.

\section{Conclusion}

Considering the fact that textbooks establish the basic materials for a language-learning course (Tomlinson, 2011), investigating their appropriateness and then selecting the most suitable ones are essential. Additionally, textbooks in most language learning classes of Iran are considered as the main source for both teaching and learning processes. To this end, the aim of the present research study was to evaluate the appropriateness of English textbook 2. According to the results, there were much more demerits than merits regarding evaluating the appropriateness of "English Textbook2". Based on the teachers' perspectives, the subject and content of the book failed to correspond to teachers' and learners' needs. Furthermore, textbook design, tasks, activities, and exercises could not encourage and persuade students for improving language proficiencies and especially communicative purposes. In addition, although according to Cunnigsworth (1995) the English textbooks should cover all the four skills, this textbook lacked the integration of the four language skills. Likewise, there was not much attention to the subskills (e.g. listening for gist, note-taking, skimming for information, etc.). Although many scholars such as Celce-Murcia (2001) declared that the textbooks should correspond to the students' needs, the findings of the current study indicated that "English textbook 2" could not match with students' educational purposes. Moreover, while according to Sheldon (1988), a suitable textbook should include graphic illustrations; it's worth mentioning that "English textbook 2" lacked this essential feature. Therefore, "English textbook 2" was not appropriate for Iranian high school students in terms of layout and design, subject and content, activities, and skills. Based on the findings of the current study, in order to accomplish the students' preferences and needs, the layout and design of the "English textbook 2" should be organized more effectively and contain various useful language learning techniques. Furthermore, the subject and content of the book should be modified. In addition, since according to Cunningsworth (1995) textbooks should match with the language learners' needs and interests, there should be interesting topics, content varieties, and useful skills and sub-skills for encouraging students to proceed with their language learning objectives. In conclusion, the findings of this study would be beneficial for materials developers, evaluators, and syllabus and curriculum designers especially for those working in the Ministry of Education. This study also suggests that it is better to conduct a new textbook for the second-grade high school or at least revise the current textbook. 
Bulletin de la Société Royale de Liège, Vol. 86, special issue, 2017, p. 111 - 126

\section{References}

1. Abdelwahab, M. M. (2013). Developing an English Language Textbook Evaluative Checklist. IOSR Journal of Research \& Method in Education, 1(3), 55-70.

2. Ahour, T., \& Ahmadi, E. (2012). Retrospective evaluation of textbook "Summit 2B" for its suitability for EFL undergraduate students. Journal of Educational and Social Research, 2(5), 195-202.

3. Ahour, T., Towhidiyan, B., \& Saeidi, M. (2014). The evaluation of "English Textbook 2" taught in Iranian high schools from teachers' perspectives. English Language Teaching, 7(3), 150.

4. Ansary, T. (2004). An analytic look at high school English textbook and introducing a sample lesson based on communicative syllabus design (Unpublished master's thesis, Islamic Azad University-Tabriz Branch, Iran).

5. Birjandy, P., Noroozi, M., \& Mahmoodi, G. (2012). English Book 2. Tehran: Textbook Publishing Company of Iran.

6. Celce-Murcia, M. (2001). Teaching English as a second or foreign language (3rd ed). Boston: Heinle \& Heinle.

7. Cunningsworth, A. (1995). Choosing your coursebook. Oxford: Heinemann Publishers Ltd. Davison, W. (1975). Factors in evaluating and selecting texts for the language classroom. ELT Journal, 30(4), 310-314.

8. Davison, W. (1975). Factors in evaluating and selecting texts for the language classroom. ELT Journal, 30(4), 310-314.

9. Dudley-Evans, T., \& St John, M. G. (2005). Developments in English for specific purposes: A multi-disciplinary approach. Cambridge: Cambridge University Press.

10. Ellis, R. (1997). SLA research and language teaching. Oxford: Oxford University Press.

11. Garinger, D. (2001). Textbook evaluation. TEFL Web Journal. Retrieved from http://www.teflwebj.org/v1n1/garinger.html

12. Garinger, D. (2002). Textbook selection for the ESL classroom. Center for Applied Linguistics Digest.

13. Ghorbani, M. R. (2011). Quantification and graphic representation of EFL textbook evaluation results. Theory and Practice in Language Studies, 1(5), 511-520. http://dx.doi.org/10.4304/tpls.1.5.511-520

14. Grant, M. (1987). Making the most of your textbook. London: Longman.

15. Hutchinson, T. (1987). What's underneath? An interactive view of materials evaluation. In L. E. Sheldon (Ed.), ELT course books and materials: Problems in evaluation and development, ELT Documents (p. 126). London: Modern English publications. The British Council.

16. Hutchinson, T., \& Waters, A. (1993). English for specific purposes: A learning-centered approach. Cambridge: Cambridge University Press.

17. Littlejohn, A. (2011). The analysis of language teaching materials: Inside the Trojan Horse. In B. Tomlinson (Ed.), Materials development in language teaching (pp. 179-211). Cambridge: Cambridge University Press. 
18. Litz, D.R.A. (2001). Textbook evaluation and ELT management: A South Korean case study. Retrieved July, 2015 from http://www.pdfgeni.com.

19. Litz, D. R. A. (2005). Textbook evaluation and ELT management: A South Korean case study. Asian EFL Journal. Retrieved November 12, 2012, from http://www.asian-efljournal.com/Litz thesis.pdf

20. McDonough, J., \& Shaw, C. (2003). Materials and methods in ELT: A teacher's guide (2nd ed.). Oxford: Blackwell Publishing.

21. Nunan, D. (1999). Second language teaching and learning. Boston: Heinle and Heinle.

22. Prabhu, N.S. (1987). Second language pedagogy. Oxford: Oxford University Press.

23. Rashidi, N., \& Kehtarfard, R. (2014). A needs analysis approach to the evaluation of Iranian third-grade high school English textbook. Sage Publication, 4(3), 1-9.

24. Razmjoo, S. A. (2010). Developing a textbook evaluation scheme for the expanding circle. Iranian Journal of Applied Language Studies, 2(1), 121-136.

25. Riasati, M. J., \& Zare, P. (2010). EFL teachers' perspectives on "New Interchange”. Studies in Literature and Language, 1(8), 54-60.

26. Riazi, A. M. (2003). "What Textbook Evaluation Schemes Tel Us? A study of the textbook evaluation schemes of three decades", in W. A. Renanda. (ed.), Methodology and Materials Design in Language Teaching, Singapore (pp. 52-68). SEAMEO Regional Center.

27. Richards, J. C. (2001). Curriculum development in language teaching. Cambridge: Cambridge University Press.

28. Sheldon, L. E. (1988). Evaluating ELT textbooks and materials. ELT Journal, 42, 237-246. http://dx.doi.org/10.1093/elt/42.4.237

29. Tok, H. (2010). TEFL textbook evaluation: From teachers' perspectives. Educational Research and Review, 5(9), 508-517. 


\section{Appendix}

Teacher textbook evaluation form (Adapted from Litz, 2005)

Dear colleagues, please provide the following information.

1) Gender: male $\square$ female

2) Teaching experience: ___ Years

The purpose behind this study is to find out the attitudes of high school teachers about "English Textbook 2". According to your personal idea, please rate the following items related to different features of the textbook.

Please choose one of the choices for each item (put X or $\sqrt{ }$ ).

Please Note:

Completely Disagree $=1$, Disagree $=2$, Moderately Agree $=3$, Agree = 4, Completely Agree $=5$

Layout and Design $\quad 1 \quad 2 \quad 345$

1. The layout and design is appropriate and clear.

2. The textbook is organized effectively.

Subject and Content $\quad \begin{array}{lllll}1 & 2 & 3 & 4 & 5\end{array}$

3. The subject and content of the textbook is relevant to my (students') needs as an English language learner(s).

4. The subject and content of the textbook is generally realistic.

5. The subject and content of the textbook is interesting, challenging and motivating.

6. There is sufficient variety in the subject and content of the textbook.

7. The materials are not culturally biased and they do not portray any negative stereotypes.

\begin{tabular}{lrrrrr}
\hline Activities & 1 & 2 & 3 & 4 & 5
\end{tabular}

8. The textbook provides a balance of activities (Ex. There is an even distribution of free vs. controlled exercises and tasks that focus on both fluent and accurate production).

9. The activities encourage sufficient communicative and meaningful practice.

10. The activities incorporate individual, pair and group work.

11. The grammar points and vocabulary items are introduced in motivating and realistic contexts.

12. The activities promote creative, original and independent responses.

13. The tasks are conducive to the internalization of newly introduced language.

14. The textbook's activities can be modified or supplemented easily. 
Bulletin de la Société Royale de Liège, Vol. 86, special issue, 2017, p. 111 - 126

15. The materials include and focus on the skills that $\mathrm{I} / \mathrm{my}$ students need to practice.

16. The materials provide an appropriate balance of the four language skills.

17. The textbook pays attention to sub-skills - i.e. listening for gist, note-taking, skimming for information, etc.

18. The textbook highlights and practices natural pronunciation (i.e.- stress and intonation)

19. The practice of individual skills is integrated into the practice of other skills. 